presence of IMP and CP resulted in about $97 \%$ inhibition of production of ammonia. This result would be expected if the enzyme responsible were the brain glutaminase described by Krebs (1935). With inorganic phosphate (5 or $10 \mu \mathrm{moles} / \mathrm{ml}$.) replacing the IMP and CP in the system, addition of glutamic acid (4 $\mu \mathrm{moles} / \mathrm{ml}$.) was accompanied by a very marked decrease in production of ammonia.

Greenstein \& Leuthardt (1948) found that bicarbonate buffer did not activate glutaminase. Further evidence for this has been found in the low blank values. They measured the stimulatory effect of various ions on glutaminase, and some organic derivatives of phosphate and arsenate. The present study has included more multivalent ions, since Greenstein \& Leuthardt (1948) had shown that univalent ions were poor stimulators of the reaction. It was concluded that, in general, as the ionic charge increased so did the effectiveness in stimulating production of ammonia (Table 5).

The effect obtained by Weil-Malherbe (1953) can be readily explained on the basis of an anion activation of brain glutaminase by phosphate formed by hydrolysis during the incubation, or by phosphate and sulphate added initially in these solutions.

\section{SUMMARY}

1. The formation of ammonia from glutamine by rat-brain particles in the presence of inosine triphosphate, or inosinic acid and creatine phosphate, is explained by the presence of low concentrations of phosphate and sulphate which activate the glutaminase present.

2. The reaction is $97 \%$ inhibited by the addition of $\mathbf{L}$-glutamic acid.
3. The effect of various other ions on the reaction was studied. The results indicated that, as the ionic charge increases, so does the efficacy in stimulating production of ammonia.

4. The synthesis of adenosine $5^{\prime}$-monophosphate from inosinic acid does not occur in this system under these conditions.

I wish to thank Professor H. A. Krebs, F.R.S., and Dr G. Weber for their interest and advice in this work. I am also indebted to the Agricultural Research Council for the award of a grant for training in research methods.

\section{REFERENCES}

Conway, E. J. (1947). Micro-diffusion Analysis and Volumetric Error, 2nd ed., pp. 77-97. London: Crosby Lockwood and Son.

Eggleston, L. V. (1954). Biochem. J. 58, 503.

Eggleston, L. V. \& Hems, R. (1952). Biochem. J. 52, 156.

Ennor, A. H. \& Stocken, L. A. (1948). Biochem. J. 43, 190. Greenstein, J. P. \& Leuthardt, F. M. (1948). Arch. Biochem. 17, 105.

Hanes, C. S. \& Isherwood, F. A. (1949). Nature, Lond., 164, 1107.

Heppel, L. A. \& Hilmoe, R. J. (1951). J. biol. Chem. 188,665. Hughes, D. E. (1950). Biochem. J. 46, 231.

Kleinzeller, A. (1942). Biochem. J. 36, 729.

Krebs, H. A. (1935). Biochem. J. 29, 1951.

Krebs, H. A. \& Hems, R. (1953). Biochem. biophys. Acta, 12 , 172.

Lehninger, A. L. (1951). In Manometric Techniques and Tissue Metabolism. Ed. by Umbreit, W. W., Burris, R. H. \& Stauffer, J. F., p. 207. Minneapolis: Burgess Publishing Co.

Ostern, P. (1932). Biochem. Z. 254, 65.

Parnas, J. K. \& Heller, J. (1924). Biochem. Z. 152, 1.

Russell, J. A. (1945). J. biol. Chem. 156, 457.

Weil-Malherbe, H. (1953). Biochem. J. 54, vi.

\title{
The Purification and Properties of Arginine Phosphokinase
}

\author{
By J. F. MORRISON, D. E. GRIFFITHS* AND A. H. ENNOR \\ Department of Biochemistry, John Curtin School of Medical Research, The Australian National University, \\ Canberra, A.C.T., Australia \\ (Received 16 May 1956)
}

Phosphocreatine and phosphoarginine have been known for many years, but in spite of their importance in the process of muscular contraction little attention has been paid to the enzymes involved in their metabolism. The first detailed studies of creatine phosphokinase were made by Noda, Kuby \& Lardy (1954), Kuby, Noda \& Lardy (1954) and Ennor \& Rosenberg (1954). The enzyme

\footnotetext{
* Australian National University Research Scholar.
}

arginine phosphokinase was first found to be present in crude extracts of crab muscle by Lohmann (1935), who showed that it was responsible for catalysing the equilibrium as expressed by the reaction phosphoarginine + adenosine diphosphate $\rightleftharpoons$ arginine + adenosine triphosphate. The presence of the enzyme in extracts of octopus muscle and the jaw muscles of the echinoid Sphaerechinus granularis was demonstrated by Lohmann (1936) and by Baldwin \& Needham (1937) respectively. Soreni, Dvornikova 
\& Degtyar (1949) reported the isolation of the enzyme in a crystalline state following ammonium sulphate fractionation of aqueous extracts of the muscles of fresh-water crabs. These workers studied only the reverse reaction and gave but a brief description of the properties of the enzyme.

The inadequacy of methods hitherto available for the isolation of phosphoarginine and the estimation of arginine have precluded detailed studies of the properties of arginine phosphokinase. The isolation of phosphoarginine in good yield from crayfish muscle (Ennor, Morrison \& Rosenberg, 1956) and the description of a sensitive and reliable procedure for the estimation of arginine (Rosenberg, Ennor \& Morrison, 1956) have provided an opportunity for a detailed study of the enzyme, and this communication reports some results with a highly active preparation of the enzyme from the tail muscle of the sea crayfish (Jasus verreauxi).

In this paper the following abbreviations will be used: ATP, adenosine triphosphate; ADP, adenosine diphosphate; PA, phosphoarginine; APK, arginine phosphokinase; EDTA, ethylenediaminetetraacetic acid; DNP, 2:4-dinitrophenol.

\section{EXPERIMENTAL}

\section{Materials and methods}

Phosphoarginine. PA was isolated from the tail muscle of the sea crayfish (Jasus lalandii) as described by Ennor et al. (1956). Solutions of the sodium salt were prepared by the careful addition of $\mathrm{Na}_{2} \mathrm{SO}_{4}$ (saturated solution) to a solution of the barium salt, and the end-point was judged by testing with sodium rhodizonate. The $\mathrm{BaSO}_{4}$ was removed by centrifuging and washed several times with water. The washings were added to the original supernatant and the solution, after adjustment to $\mathrm{pH} 7 \cdot 2$ by the addition of $\mathrm{N}-\mathrm{HCl}$, was made up to volume. This method gave a quantitative recovery of PA and the resultant solution contained less than $0.2 \%$ of free arginine.

Adenosine triphosphate and adenosine diphosphate. Both were commercial samples (Sigma Chemical Co.) of the hydrated sodium salts of over $95 \%$ purity. Paper electrophoretic examination showed that the ATP contained traces of ADP, and the ADP contained traces of adenosine $5^{\prime}$-phosphate. The ATP also contained $0 \cdot 3 \%$ of inorganic $P$. Solutions of ATP were initially pH 3.6 but were immediately adjusted to $\mathrm{pH} 8.5$ by the addition of $\mathrm{N}-\mathrm{NaOH}$ before making to volume. With ADP no such adjustment was necessary and the solutions were used at $\mathrm{pH} 7 \cdot 6$. The concentrations of both were checked by measurement of the absorption at $260 \mathrm{~m} \mu$. of dilutions in $0 \cdot 1 \mathrm{~N}-\mathrm{HCl}$ by assuming a molecular extinction value for adenosine $5^{\prime}$-phosphate of $14.9 \times 10^{3}$.

Adenylic acid. Adenosine 5'-phosphate was prepared from ATP by the action of apyrase and was purified as described by Kerr (1941). It was obtained as the crystalline free acid and was stored as such. Solutions were made up as required and adjusted to $\mathrm{pH} 7 \cdot 4$ by the addition of $\mathrm{N}-\mathrm{NaOH}$.

Inosine triphosphate. This was prepared from ATP by the method of Kleinzeller (1942).
Arginine. A commercial sample (British Drug Houses Ltd.) of L-arginine monohydrochloride was used without recrystallization. The purity was checked by $\mathrm{N}$ analysis. Solutions were made up as required and adjusted to $\mathrm{pH} 8.5$ by the addition of $\mathrm{N}-\mathrm{NaOH}$.

Other guanidino compounds. Creatine and glycocyamine were obtained from British Drug Houses Ltd. L-Canavanine sulphate was obtained from the California Foundation for Biochemical Research. Agmatine sulphate was obtained from Light and Co. Ltd. These compounds were used without recrystallization. Argininic acid was synthesized in poor yield by the method of Felix \& Schneider (1938). $\alpha$-Carbamidoarginine was synthesized by the method of Boon \& Robson (1935). L-Homoarginine was synthesized by the method of Stevens \& Bush (1950). Arginine methyl ester dihydrochloride was synthesized from arginine monohydrochloride by the method of Fischer \& Suzuki (1905). Negmine ( $N$-ethylglycocyamine) was a gift from $\mathrm{Dr}$ Armstrong of the University of Utah, U.S.A. Taurocyamine was prepared by the guanylation of taurine with S-ethylthiourea hydrobromide, as described by Brand \& Brand (1942). $\beta$-Guanidopropionic acid and $\delta$-guanido- $n$-valeric acid were prepared by the guanylation of $\beta$-alanine and $\delta$-amino- $n$-valeric acid respectively with $O$-methylisourea hydrochloride, according to the general method of Schutte (1943). The $\delta$-amino- $n$-valeric acid used was prepared from cyclopentanone by the following reaction sequence: cyclo-

pentanone $\longrightarrow$ cyclopentanone oxime $\longrightarrow \alpha$-piperidone $\longrightarrow$ $\delta$-amino- $n$-valeric acid HCl. Reaction (1) was carried out by the procedure described by Bousquet (1943) for the synthesis of heptaldoxime. Reactions (2) and (3) were carried out as described by Schniepp \& Marvel (1935).

All compounds were recrystallized twice before use, and were pure as judged by the melting point and one-dimensional paper chromatography in propanol-ammonia-water $(60: 30: 10)$.

Solutions of PA, ATP, ADP, adenosine 5'-phosphate and arginine were stored at $-15^{\circ}$.

Buffer systems. N-Ethylmorpholine (Eastman Kodak) was redistilled under reduced pressure before use. The components of other buffer systems were products of British Drug Houses Ltd.

Inhibitors. $p$-Chloromercuribenzoic acid was a Sigma Chemical Co. product. Diphenylchloroarsine was a gift from Sir Rudolph Peters, F.R.S. o-Iodosobenzoic acid and $N$-ethylmaleimide were gifts from Drs K. Pausacker and F. Hird of the University of Melbourne. Other inhibitors were products of British Drug Houses Ltd.

\section{Estimation of protein}

Protein was estimated colorimetrically by the biuret method of Gornall, Bardawill \& David (1949), crystalline ox-serum albumin being used as the standard.

\section{Determination of enzymic activity}

Unless otherwise stated, the following techniques were used to determine the activity of the enzyme:

Foruard reaction: $P A+A D P \rightarrow$ Arginine $+A T P$. To $10 \mathrm{ml}$. graduated test tubes was added $0.8 \mathrm{ml}$. of a stock solution containing $0.1 \mathrm{ml}$. of $0.5 \mathrm{M} N$-ethylmorpholine $\left(\mathrm{pH} \mathrm{7.2)}, 0.1 \mathrm{ml}\right.$. of $0.05 \mathrm{M} \mathrm{PA}, 0.1 \mathrm{ml}$. of $0.1 \mathrm{M}-\mathrm{MgSO}_{4}$, $0.1 \mathrm{ml}$. of $0.01 \mathrm{M} \mathrm{ADP}$ and $0.4 \mathrm{ml}$. of water. The tubes were 
equilibrated in a water bath at $5^{\circ}$ and the reaction was started by the addition of $0.2 \mathrm{ml}$. of APK solution. The APK solution was diluted to the required concentration in buffer $(0.05 \mathrm{M}, \mathrm{pH} \mathrm{7.2)}$; this gave a final buffer concentration of $0.06 \mathrm{M}$. At the end of the incubation period the reaction was stopped by the addition of $1.0 \mathrm{ml}$. of an EDTA-NaOH mixture containing $0.4 \mathrm{ml}$. of $0.2 \mathrm{M}$ EDTA (adjusted to $\mathrm{pH} \mathrm{7.6)}$ and $0.6 \mathrm{ml}$. of $5 \mathrm{~N}-\mathrm{NaOH}$. The arginine released in the reaction was estimated in the same tubes by the method of Rosenberg et al. (1956) without any further addition of $\mathrm{NaOH}$. Under these conditions, the reaction followed zeroorder kinetics.

Reverse reaction: Arginine $+A T P \rightarrow P A+A D P$. The velocity of the reverse reaction was determined by acid hydrolysis of the PA formed and estimation of the inorganic $P$ released. To $10 \mathrm{ml}$. graduated test tubes was added $0.8 \mathrm{ml}$. of a stock solution containing $0.1 \mathrm{ml}$. of $0.1 \mathrm{~m}$ arginine, $0.1 \mathrm{ml}$. of $0.05 \mathrm{M} \mathrm{ATP}, 0.1 \mathrm{ml}$. of $0.1 \mathrm{M}-\mathrm{MgSO}_{4}, 0.1 \mathrm{ml}$. of $0.5 \mathrm{~m} \mathrm{~N}$-ethylmorpholine ( $\mathrm{pH} \mathrm{8.4)}$ ) and $0.4 \mathrm{ml}$. of water. The tubes were equilibrated in a water bath at $5^{\circ}$ and the reaction was started by the addition of $0.2 \mathrm{ml}$. of APK solution. The enzyme was diluted in $N$-ethylmorpholine $(0.05 \mathrm{M}, \mathrm{pH} \mathrm{8.4)}$, making the final buffer concentration $0.06 \mathrm{M}$. The reaction was stopped by the addition of $1.0 \mathrm{ml}$. of $0.2 \mathrm{~N}$ trichloroacetic acid, the tubes were removed from the bath and placed in boiling water for $1 \mathrm{~min}$. (Under these conditions PA is quantitatively hydrolysed to arginine and inorganic $\mathbf{P}$.) They were then rapidly cooled by agitation in an ice bath and the inorganic $P$ was estimated by a modification of the method of King (1932). The reagents [ $2.0 \mathrm{ml}$. of $5 \%(w / v)$ ammonium molybdate in $15 \%(v / v) \mathrm{H}_{2} \mathrm{SO}_{4}$ and $0.5 \mathrm{ml}$. of the reducing agent] were added to each tube at half-minute intervals. The volume was adjusted to $10.0 \mathrm{ml}$. by the addition of water and the contents were mixed. Colour intensities were measured at 30 sec. intervals, $10 \mathrm{~min}$. after the addition of the above reagents. (It should be noted that concentrations of $N$-ethylmorpholine greater than $0.08 \mathrm{M}$ interfere with the determination of inorganic $P$.)

When the reaction velocity is determined by the estimation of inorganic $P$ arising from $P A$ as a result of hydrolysis in trichloroacetic acid, allowance has to be made for the inorganic $P$ present in the ATP and that released from ATP as a result of hydrolysis in $0.1 \mathrm{~N}$ trichloroacetic acid at $100^{\circ}$ and in acid molybdate during colour development. The correction may be determined in one of two ways, both of which should give the same value: (i) the complete system is stopped at zero time with trichloroacetic acid, the mixture heated at $100^{\circ}$, the colour developed and the extinction value determined at a fixed time after colour development. The value so obtained is then subtracted from the extinction values obtained after a similar treatment of the reaction system following incubation. Alternatively, (ii) the reaction is carried out for various time periods and treated as described above. The slope of the line obtained as a result of the extrapolation to zero time of a plot of the extinction values against reaction time gives a measure of the reaction velocity. The correction value is given by the point where the line cuts the ordinate. Experimentally it has been found that method (ii) gives a value which is about $10 \%$ higher than that obtained by method (i), and it seems likely that this is the correct zero-time value; for when this correction is used the reaction rate is proportional to the enzyme concentration. For this reason method (ii) has been used throughout this work, although no explanation can be offered for the difference mentioned. Careful attention was paid to the development time and hydrolysis conditions.

Arbitrary units of APK activity. One unit of APK activity, in the forward reaction, is defined as the amount of enzyme which releases $1 \mu$ mole of arginine from PA in 1 min. at pH $7 \cdot 2$ and at $5^{\circ}$.

Specific activity is defined as the number of units of APK/ mg. of protein.

\section{RESULTS}

\section{Preparation of arginine phosphokinase}

Sea crayfish were used as the source of APK because of the large muscle mass and because they were available throughout the year. Attempts made to isolate the enzyme from this source by the method developed by Soreni et al. 1949 for fresh-water crab muscle were unsuccessful, and it was found that the fractionation pattern for APK from sea-crayfish muscle differed considerably from that for APK from fresh-water crab muscle. Therefore, attention was turned to the development of a method for the isolation of the enzyme from sea-crayfish muscle. This method is given below.

Extraction of tissue. Live crayfish (Jasus verreauxi) were obtained from sea-water storage pens and transported to the laboratory in bags packed with wet seaweed. All specimens arrived in good condition. From this stage onwards, all operations were carried out in the cold room at $5^{\circ}$. The tail muscles of six live crayfish were rapidly excised and passed twice through a mincer. A sample $(500 \mathrm{~g}$.) of the minced muscle was extracted by stirring with 3 vol. of water for $30 \mathrm{~min}$. and then centrifuged for $15 \mathrm{~min}$. at $1000 \mathrm{~g}$ and $0^{\circ}$. The product did not sediment well and it was necessary to pour off carefully the opalescent uppermost layer from the middle gelatinous layer. The two bottom layers were extracted with 1.5 vol. of water $(750 \mathrm{ml}$.) by stirring for $30 \mathrm{~min}$., and again centrifuged at $1000 \mathrm{~g}$ for $15 \mathrm{~min}$. at $0^{\circ}$. The opalescent supernatant was poured off from the firmly packed residue and combined with the first extract. The $\mathrm{pH}$ of the combined extracts was 6.6. Both these extracts were of the same specific activity, and further quantities of the enzyme, also of the same specific activity, could be obtained as a result of a third extraction with 1.5 vol. of water. This extract contained only a small amount of protein and was discarded.

First ammonium sulphate fractionation. For convenience, two $500 \mathrm{ml}$. samples of the extract were taken and fractionated simultaneously. Solid $\left(\mathrm{NH}_{4}\right)_{2} \mathrm{SO}_{4}(31.5 \mathrm{~g}$. $/ 100 \mathrm{ml}$.) was added slowly to each sample with mechanical stirring. The precipitate was removed by centrifuging at $5000 \mathrm{~g}$ for $10 \mathrm{~min}$. at $0^{\circ}$ and discarded. To the clear, colourless supernatant solid $\left(\mathrm{NH}_{4}\right)_{2} \mathrm{SO}_{4}(10.5 \mathrm{~g} . / 100 \mathrm{ml}$. of original extract) was added slowly with mechanical stirring. A grey precipitate was removed by centrifuging at $5000 \mathrm{~g}$ for $10 \mathrm{~min}$. at $0^{\circ}$ from a clear, colourless supernatant, which was discarded. The two precipitates were each dissolved in $100 \mathrm{ml}$. of water and combined.

Second ammonium sulphate fractionation. Ammonia soln. $(17 \mathrm{~N})$ was added to a saturated solution of $\left(\mathrm{NH}_{4}\right)_{2} \mathrm{SO}_{4}$ at $5^{\circ}$ so that (on testing a dilution of 1 in 10 ) the $\mathrm{pH}$ was 8.2. This solution was added dropwise with mechanical stirring to the 
enzyme solution obtained from the previous step until $\mathbf{0 \cdot 7}$ saturation was reached. The grey precipitate was removed by centrifuging at $5000 \mathrm{~g}$ for $10 \mathrm{~min}$. at $0^{\circ}$ and discarded. The supernatant was then brought to 0.8 saturation by the further addition of the alkaline $\left(\mathrm{NH}_{4}\right)_{2} \mathrm{SO}_{4}$ solution. The suspension was centrifuged at $5000 \mathrm{~g}$ for $15 \mathrm{~min}$. at $0^{\circ}$, the supernatant discarded and the white precipitate dissolved in water to give a final volume of $50 \mathrm{ml}$.

Attempts to increase the specific activity of this enzyme preparation were unsuccessful. Low-temperature fractionation with both ethanol and propanol at pH 6.6 and 8.2 in the presence and absence of magnesium led to marked loss of activity. The enzyme was not precipitated by $\mathrm{MgSO}_{4}$.

Although APK constituted the major portion of the final product, it could not be induced to crystallize. The addition of saturated $\left(\mathrm{NH}_{4}\right)_{2} \mathrm{SO}_{4}$ solutions of varying $\mathrm{pH}$ in amounts just insufficient to cause precipitation gave rise to amorphous precipitates only.

The summary of the yields and degrees of purification of APK (Table 1) obtained with a typical preparation indicated that this fractionation procedure gives approximately a threefold increase in the purity of the enzyme with an overall recovery of $21 \%$.

\section{Tests for the presence of other enzymes in the $A P K$ preparation}

Tests for the presence of phosphoamidase, ATPase and myokinase activities in the APK preparation were carried out in the forward reaction system with the enzyme at a concentration 1000 times greater than that used in the standard-activity determination. Phosphoamidase activity was tested for at $\mathrm{pH} 7.2$ and 8.4 by determination of any arginine released from PA in the absence of ADP; no such activity was detected. When ADP was replaced by ATP there was again no release of arginine, indicating the absence of a $\mathbf{M g}^{2+}$ ionactivated ATPase, which conclusion is confirmed by the fact that there was no release of inorganic $P$ when the enzyme was incubated with ATP. The replacement of ADP by ATP and adenosine $5^{\prime}$ phosphate led to the release of arginine. Thus an enzyme with myokinase-like activity was a contaminant of the preparation; but it was concluded that this was a minor contaminant for when tests were made at the usual level of $1 \mu \mathrm{g}$. of protein $/ \mathrm{ml}$. no trace of activity could be detected.

\section{Electrophoretic analysis}

The electrophoretic pattern of the final preparation of APK is illustrated in Fig. 1. All the components migrated to the anode at $\mathrm{pH} \mathrm{8.6.} \mathrm{An}$ attempt was made to carry out a second run in acetate buffer (pH 5.7), but on dialysis of the enzyme against the buffer before electrophoresis, there was a marked precipitation of protein. It was not possible to redissolve the precipitate by dialysis against buffers with higher $\mathrm{pH}$ values. From a study of the effects of $\mathrm{pH}$ on the enzymic activity and protein content of the APK solution the enzyme appears to have an isoelectric point near $\mathrm{pH} 5$. Because of the rapid denaturation of the enzyme at $\mathrm{pH}$ values below $\mathbf{5 \cdot 7}$, it was not possible to carry out an electrophoretic run at $\mathrm{pH}$ values where the protein would be positively charged. It was calculated that at pH 8.6 the major component consti-

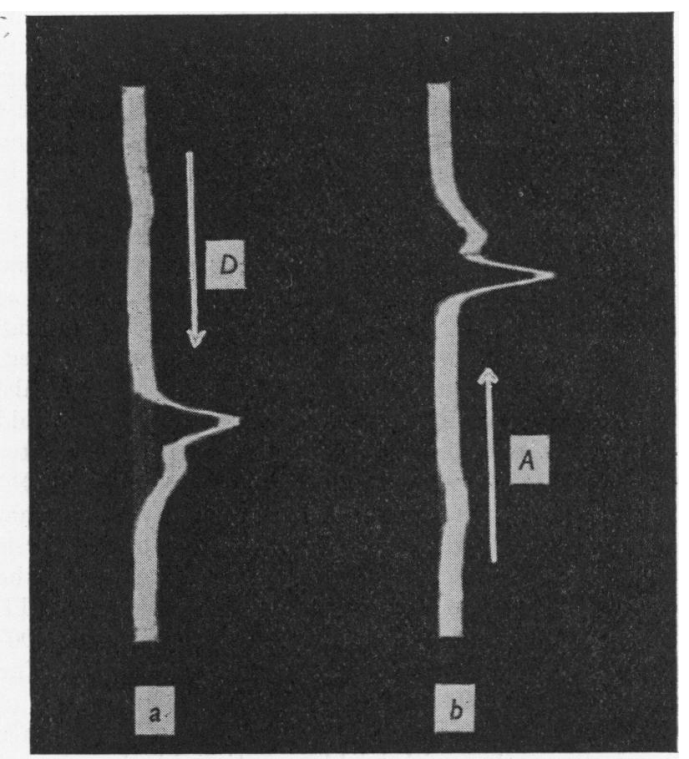

Fig. 1. Electrophoretic patterns of the APK preparation obtained after fractionation as described in the text. Veronal buffer, $\mathrm{pH} 8 \cdot 6$; ionic strength, 0.1 ; temperature, $1^{\circ}$; field strength, $6.6 \mathrm{v} / \mathrm{cm}$.; protein concentration, $1 \%$; time, 272 min. $a$, Descending boundary; $b$, ascending boundary.

Table 1. Summary of yields and specific activities of fractions obtained during the fractionation of $A P K$

Wt. of muscle, $500 \mathrm{~g}$. Details are described in the text.

\begin{tabular}{|c|c|c|c|c|c|}
\hline Fraction & $\begin{array}{l}\text { Volume } \\
\text { (ml.) }\end{array}$ & $\begin{array}{c}\text { Total protein } \\
\text { (g.) }\end{array}$ & Total units & $\begin{array}{l}\text { Specific } \\
\text { activity }\end{array}$ & $\begin{array}{c}\text { Recovery } \\
(\%)\end{array}$ \\
\hline Extract & 2050 & $22 \cdot 1$ & 530000 & 24 & $(100)$ \\
\hline First ammonium sulphate ppt. & 570 & $8 \cdot 3$ & 282000 & 34 & 53 \\
\hline Second ammonium sulphate ppt. & 54 & $1 \cdot 7$ & 110000 & 67 & 21 \\
\hline
\end{tabular}


tuted $67 \%$ of the total protein and had a mobility of $-2.84 \times 10^{-5} \mathrm{~cm}^{2} \mathrm{v}^{-1}$ sec..$^{-1}$.

In order to determine whether or not the main component was responsible for the APK activity, the protein solution was dialysed against $0.04 \mathrm{M}$ phosphate buffer ( $\mathrm{pH}$ 7.4) and subjected to paper electrophoresis. Fig. 2 shows that staining with bromophenol blue (personal communication from Dr W. E. van Heyningen, 1954) indicates the presence of a major component and a faster-moving minor component. From a second paper strip run at the same time areas corresponding to the stained sections were excised and added to the standard-test system for the forward reaction. The results showed that the major, slower-moving component possessed APK activity, whereas the faster-moving component showed none. The components showed neither myokinase nor phosphoamidase activity.

Elution of the stained protein bands as described by Durrum (1955) and subsequent determination of the optical density indicated that APK constituted $80 \%$ of the total protein. This compares with a value of $67 \%$ obtained from the run in the Tiselius electrophoresis apparatus.

The fact that a preparation of high purity was obtained with only a threefold increase in specific activity indicates that APK forms a high proportion of the protein of the muscle extract. This is also indicated by the finding that only four components could be detected in the extract by paper electrophoresis.

\section{General properties of $A P K$}

The APK preparation could be dialysed against water and $N$-ethylmorpholine and phosphate buffers $(0.05 \mathrm{M}, \mathrm{pH} \mathrm{7.2)}$ without loss of enzymic activity. There was no loss of activity when the protein solution was freeze-dried after dialysis against phosphate buffer, but after dialysis against water freeze-drying led to an almost complete loss of activity. When water was added to the water- dialysed, freeze-dried protein the solution was opalescent and the $\mathrm{pH}$ was 4.4 ; this low $\mathrm{pH}$ presumably accounts for the loss of activity. Freezing and thawing (four times) of a $1 \%(w / v)$ aqueous solution of the enzyme ( $\mathrm{pH} 7$ ) produced no loss of activity. Although the enzyme could be dialysed against phosphate buffer and freeze-dried, it was more convenient to store the solution at $5^{\circ}$ in the presence of an equal volume of glycerol. This dilution was made after determination of the protein content by the biuret method to avoid interference by the glycerol. Suitable reaction rates were obtained with high dilutions of the glycerol solution so that the concentrations of glycerol and $\left(\mathrm{NH}_{4}\right)_{2} \mathrm{SO}_{4}$ in the final reaction mixture were such that they had no effect on the activity of the enzyme.

The initial specific activity of all APK preparations (67-80) fell during the first 2-3 days of storage to a value of 46. This decrease in activity was independent of the method of storage but after its occurrence the specific activity of the glycerol solutions of APK remained constant for at least 12 months. In the absence of glycerol further changes occurred after the first 2-3 days : thus it was found that aqueous and $\left(\mathrm{NH}_{4}\right)_{2} \mathrm{SO}_{4}$ solutions of the enzyme became opalescent within a week and a precipitate settled on the walls of the vessel. There was, however, no fall in the specific activity of the supernatant. On the other hand, glycerol solutions of the enzyme remained clear.

Effect of temperature and dilution on APK activity . The initial experiments designed to determine APK activity in the forward reaction were carried out at $30^{\circ}$ but the results were unreliable. This was at first believed to be due to the effect of temperature on the enzyme, and an incubation temperature of $5^{\circ}$ was then chosen. However, even at this temperature it was found that the observed specific activity varied with the degree to which the enzyme was diluted before the addition to the test medium. Thus

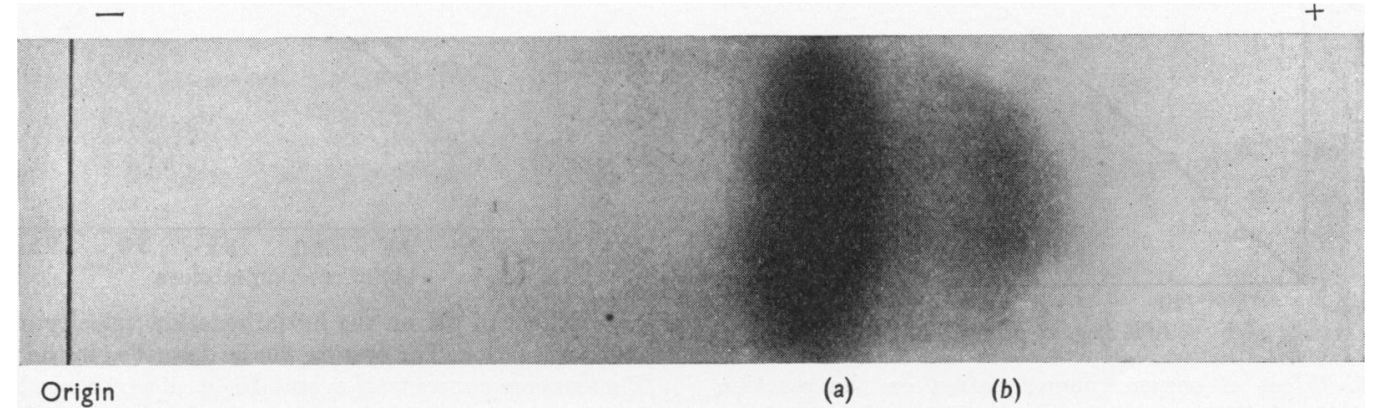

Fig. 2. Separation by paper electrophoresis of the proteins of the APK preparation obtained as described in the text. Phosphate buffer $(0.04 \mathrm{M}, \mathrm{pH} \mathrm{7 \cdot 4})$ containing $5 \%(\nabla / v)$ ethylene glycol; current, $8 \mathrm{~mA}$; time, $22 \mathrm{hr}$; temperature, $22^{\circ}$. $a, \mathrm{APK} ; b$, contaminating protein. 
a large volume of highly diluted enzyme was not as active as a small volume of a correspondingly more concentrated enzyme, even though the reaction rate was constant in all cases. This indicates that there is no inactivation of APK as a result of enzyme dilution in the presence of substrate; inactivation therefore occurs as a result of the initial dilution of the enzyme with buffer. This effect was most marked when the concentration of protein in the diluted enzyme solution was less than $2.5 \mu \mathrm{g}$. $/ \mathrm{ml}$. and absent at concentrations greater than $5 \mu \mathrm{g} . / \mathrm{ml}$. This inactivation of the enzyme at high dilutions was apparently not due to oxidation of - $\mathrm{SH}$ groups, for the effect was still observed even when the enzyme was diluted in the presence of cysteine. A temper-

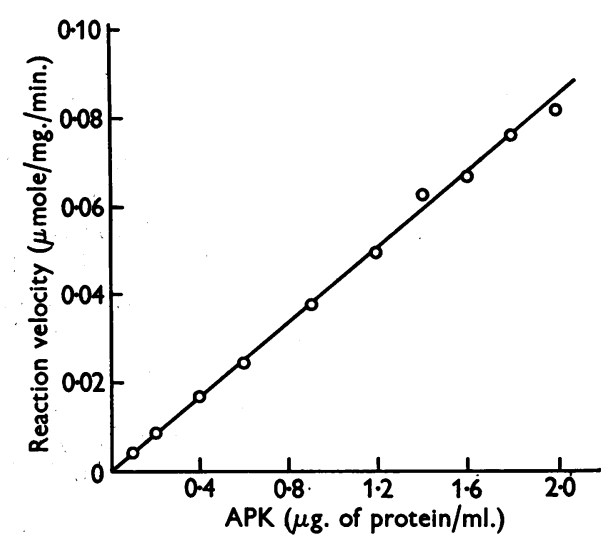

Fig. 3. Effect of enzyme concentration on the reaction velocity of the forward reaction at $\mathrm{pH} \mathbf{7 \cdot 2}$. Conditions as described in the text, except that various volumes of a stock enzyme solution ( $5 \mu \mathrm{g}$. of protein $/ \mathrm{ml}$.) were added. Reaction time, 4 min.; temperature, $5^{\circ}$.

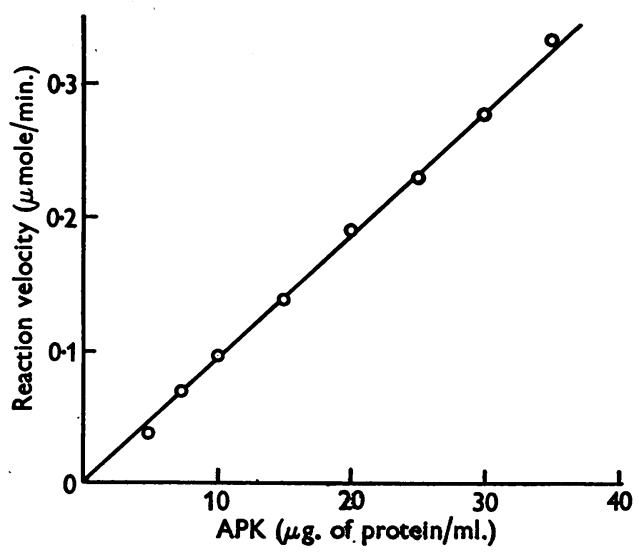

Fig. 4. Effect of enzyme concentration on the reaction velocity of the reverse reaction at $\mathrm{pH} 8.4$. Conditions as described in the text, except that various volumes of a stock enzyme solution ( $100 \mu \mathrm{g}$. of protein $/ \mathrm{ml}$.) were added. Reaction time, 3, 6 and 9 min.; temperature, $5^{\circ}$. ature of $5^{\circ}$ was chosen for all subsequent work as the reaction rate was slowed sufficiently to permit the use of larger amounts of enzyme and thus to avoid inactivation of the type referred to above.

Effect of enzyme concentration on the reaction velocity. The initial velocity is proportional to the enzyme concentration in both the forward and reverse reactions over the concentration range studied (Figs. 3, 4). It will be noted that the velocity of the forward reaction is about five times as fast as the reverse reaction.

Effect of $\mathrm{pH}$ on the reaction velocity. The relation. ship between $\mathrm{pH}$ and reaction velocity in the forward reaction (Fig. 5) indicates that maximum velocity is reached at $\mathrm{pH} 6.8$ in phosphate, at

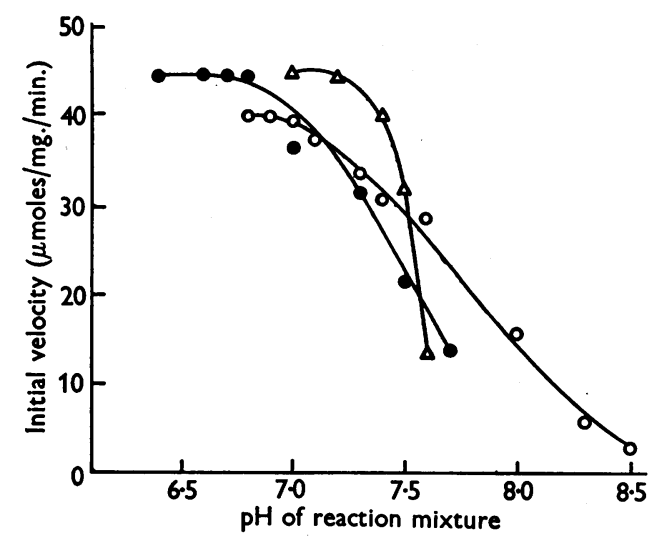

Fig. 5. Effect of $\mathrm{pH}$ on the initial reaction velocity of the forward reaction. The system was as described in the text. The enzyme concentration was $1 \mu \mathrm{g}$. of protein $/ \mathrm{ml}$. and reactions were run for 3 and $6 \mathrm{~min}$. The $\mathrm{pH}$ was determined with a glass electrode in a duplicate set of tubes. Temperature, $5^{\circ}$. $\mathrm{O}, N$-Ethylmorpholine (0.06 M); , phosphate $(0.06 \mathrm{M}) ; \triangle$, glycerophosphate $(0.06 \mathrm{M})$.

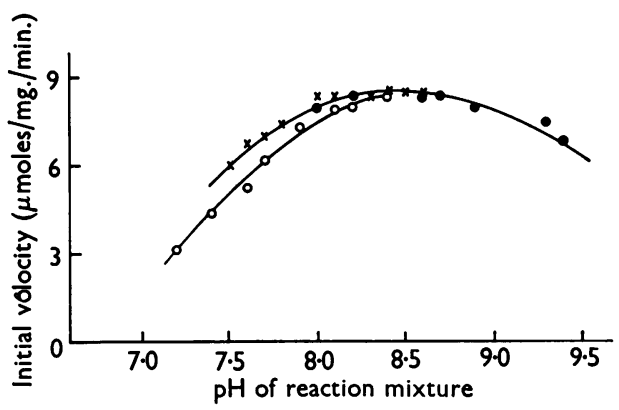

Fig. 6. Effect of $\mathrm{pH}$ on the initial reaction velocity of the reverse reaction. The system was as described in the text. The enzyme concentration was $15 \mu \mathrm{g}$. of protein $/ \mathrm{ml}$. and reactions were run for 5,10 and $15 \mathrm{~min}$. The $\mathrm{pH}$ was determined with a glass electrode in a duplicate set of tubes. Temperature, $5^{\circ}$. O, $N$-Ethylmorpholine $(0.06 \mathrm{M})$; , glycine $(0.06 \mathrm{M}) ; \times$, glycylglycine $(0.06 \mathrm{M})$. 
$\mathrm{pH} 7 \cdot 2$ in glycerophosphate and at $\mathrm{pH} \mathrm{7.0}$ in $N$. ethylmorpholine. At the $\mathrm{pH}$ optimum, the reaction rates were the same in phosphate and glycerophosphate, but were slightly lower in $N$-ethylmorpholine. Although the $\mathrm{pH}$ optimum in $N$ ethylmorpholine is at pH $7 \cdot 0$, further experiments on the forward reaction in this buffer were carried out at $\mathrm{pH} 7 \cdot 2$, as better buffering capacity was obtained at this $\mathrm{pH}$. Aminotrishydroxymethylmethane was not used as a buffer because it interferes with the estimation of arginine (cf. Rosenberg et al. 1956).

In the reverse reaction (Fig. 6) the pH-activity curves show that the optimum $\mathrm{pH}$ is about 8.4 in $N$-ethylmorpholine, glycine and glycylglycine buffers. At this $\mathrm{pH}$ the reaction velocity is the same in each of the three buffers.

Activation of $A P K$ by bivalent cations. The purified APK preparation shows only a small residual activity in the absence of bivalent cations (Fig. 7). The activity of the enzyme in the forward reaction is markedly increased by the addition of $\mathrm{Mg}^{2+}$ ions but $\mathrm{Ca}^{2+}$ ions are without effect. Although $\mathrm{Mn}^{2+}$ ions also activated the enzyme, these ions interfere with the arginine estimation by the formation of coloured ions in alkaline solution and so it was not possible to obtain a precise figure for the degree of activation. In the reverse reaction (Fig. 8) it was possible to demonstrate activation of the enzyme by both $\mathrm{Mg}^{2+}$ and $\mathrm{Mn}^{2+}$ ions, but here again there was no activation by $\mathrm{Ca}^{2+}$ ions. There was no activation of $\mathrm{APK}$ by $\mathrm{Ba}^{2+}, \mathrm{Sr}^{2+}, \mathrm{Ni}^{2+}, \mathrm{Fe}^{2+}, \mathrm{Co}^{2+}, \mathrm{Cu}^{2+}, \mathrm{Cd}^{2+}$,

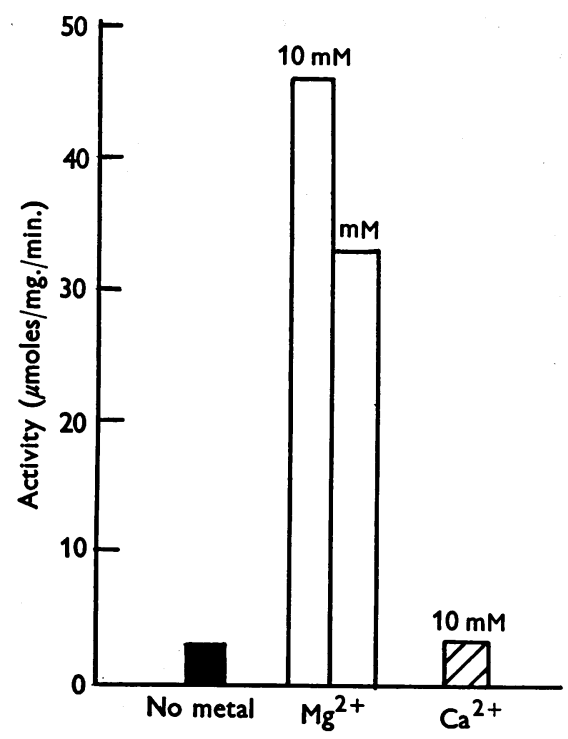

Fig. 7. Activation of APK by bivalent metals as determined in the forward reaction. Conditions as described in the text. Temperature, $5^{\circ}$.
$\mathrm{Zn}^{2+}, \mathrm{Fe}^{3+}$ and $\mathrm{Al}^{3+}$ ions as tested in the reverse reaction.

The activity of the APK preparation in the absence of added ions (residual activity) was not removed by dialysis against 0.01 M EDTA (pH 7.2) for $18 \mathrm{hr}$., followed by dialysis against water. However, when EDTA (0.01 M) was added to the test medium there was a complete loss of residual activity.

Effect of inhibitors on APK activity. The effect of inhibitors on APK activity in the forward reaction is summarized in Table 2. The inhibition by iodoacetate, $p$-chloromercuribenzoate, 0 -iodosobenzoate, $N$-ethylmaleimide and diphenylchloroarsine characterizes APK as an -SH enzyme. The enzyme is very sensitive to $p$-chloromercuribenzoate, $100 \%$ inhibition being obtained at $10^{-7} \mathrm{M}$. The high affinity of the enzyme for $\mathrm{Mg}^{2+}$ ions is indicated by the fact that an EDTA:Mg ratio of 2:1 is required for complete inhibition at $\mathrm{pH} \mathbf{7 \cdot 2}$. The inhibition by DNP is unusual, as this compound has not been shown to inhibit transphosphorylation at the substrate level. The nature of the inhibition was further investigated and it was found that when tests were made on the reverse reaction at $\mathrm{pH} 8.4$ and $\mathrm{pH} \mathrm{7.2}$ no inhibition resulted. A similar result was obtained with tests on the forward reaction at $\mathrm{pH} 8.4$. It thus seems that DNP has no effect on transphosphorylation; its inhibitory action on the forward reaction at $\mathrm{pH} 7.2$ may therefore be due to inter. action with one of the substrates.

Specificity of $A P K$. The ability of APK to phosphorylate other guanidine compounds was deter; mined in the reverse reaction by estimating both the disappearance of free guanidine and the formation of acid-labile $P$. With canavanine it was possible to determine only the formation of acid-labile $P$, as

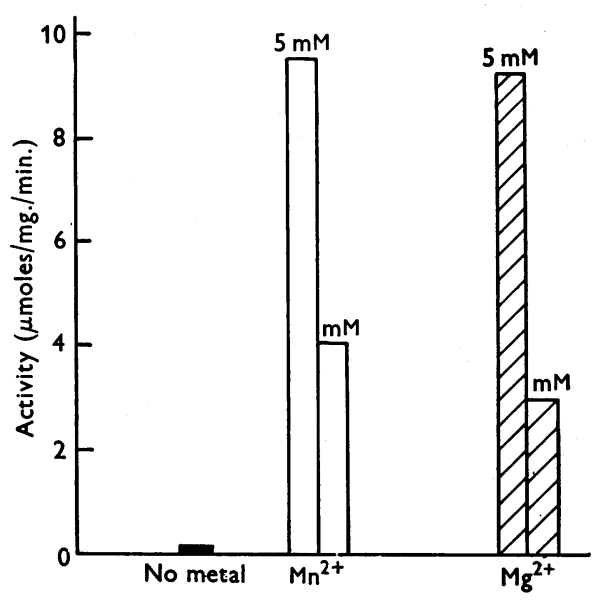

Fig. 8. Activation of APK by bivalent metals as determined in the reverse reaction. Conditions as described in the text. Temperature, $5^{\circ}$. 
this compound does not give the guanidine colour reaction with $\alpha$-naphthol and diacetyl. It can be seen (Table 3) that besides arginine there was also phosphorylation of arginine methyl ester, Lhomoarginine and L-canavanine. However, the degree to which these compounds were phosphorylated was less than with arginine. There was no phosphorylation of agmatine, creatine, glycocyamine, taurocyamine, negmine, citrulline, argininic acid, $\delta$-guanido- $n$-valeric acid, $\beta$-guanidopropionic acid or $\alpha$-carbamidoarginine.

These latter compounds as well as canavanine and homoarginine had no effect on the rate at which arginine was phosphorylated when present in equimolar concentrations. Under the standard-test conditions arginine methyl ester was phosphorylated at the same rate as arginine, whereas the rates of phosphorylation of homoarginine and canavanine were negligible.

The enzyme is specific for ADP in the forward reaction; adenosine 5 '-phosphate does not act as a phosphate acceptor. In the reverse reaction, ATP could not be replaced by inosine triphosphate or ADP.

\section{Isolation of APK from the tail muscle of Cherix albidus}

Specimens of fresh-water crayfish (Cherix albidus Clark) are available only in the summer months. On completion of the work on APK isolated from seawater crayfish an attempt was made to isolate the enzyme from the tail muscle of Cherix albidus by the procedure described by Soreni et al. (1949).

The precipitate formed by the addition of $\left(\mathrm{NH}_{4}\right)_{2} \mathrm{SO}_{4}(43.2 \mathrm{~g} . / 100 \mathrm{ml}$.) to the extract was removed by filtration and the filtrate allowed to stand for $48 \mathrm{hr}$. at $5^{\circ}$. No crystalline material was formed but the amorphous precipitate which appeared after $18 \mathrm{hr}$. contained large amounts of APK of high specific activity (90). Electrophoretic analysis of this fraction in veronal buffer $(\mu=0 \cdot 1)$ at pH 8.6 showed the presence of three components, and it was estimated that APK constituted about $50 \%$ of the total protein present.
Table 2. Effect of various substances on APK activity in the forward reaction

The enzyme $(1 \mu \mathrm{g} . / \mathrm{ml}$.) was incubated for $5 \mathrm{~min}$. in the presence of the inhibitor, $N$-ethylmorpholine $(0.06 \mathrm{M}$, $\mathrm{pH} 7 \cdot 2), \mathrm{PA}(5 \mathrm{~mm})$ and $\mathrm{Mg}^{2+}$ ions $(5 \mathrm{mM})$. The reaction was started by the addition of ADP (mM) and stopped after $5 \mathrm{~min}$. Total volume, $1.0 \mathrm{ml}$; temp. $5^{\circ}$.

\begin{tabular}{|c|c|c|}
\hline & Concentratior & nhibition \\
\hline Compound & & $(\%)$ \\
\hline Iodoacetate & $\begin{array}{l}1 \times 10^{-2} \\
1 \times 10^{-8}\end{array}$ & $\begin{array}{l}92 \\
19\end{array}$ \\
\hline$p$-Chloromercuribenzoate & $\begin{array}{l}1 \times 10^{-7} \\
1 \times 10^{-8}\end{array}$ & $\begin{array}{r}100 \\
27\end{array}$ \\
\hline$o$-Iodosobenzoate & $\begin{array}{l}1 \times 10^{-3} \\
1 \times 10^{-4} \\
1 \times 10^{-5}\end{array}$ & $\begin{array}{r}100 \\
67 \\
19\end{array}$ \\
\hline$N$-Ethylmaleimide & $\begin{array}{l}1 \times 10^{-4} \\
1 \times 10^{-5}\end{array}$ & $\begin{array}{l}85 \\
10\end{array}$ \\
\hline Diphenylchloroarsine & $\begin{array}{l}1 \times 10^{-4} \\
1 \times 10^{-5}\end{array}$ & $\begin{array}{l}55 \\
12\end{array}$ \\
\hline Chloroacetophenone & $1 \times 10^{-4}$ & $\mathbf{0}$ \\
\hline Arsenite & $1 \times 10^{-3}$ & 0 \\
\hline Ethylenediaminetetraacetic acid & $\begin{array}{l}2 \times 10^{-2} \\
1 \times 10^{-2} \\
5 \times 10^{-8}\end{array}$ & $\begin{array}{r}100 \\
95 \\
32\end{array}$ \\
\hline Dinitrophenol & $\begin{array}{l}1 \times 10^{-8} \\
1 \times 10^{-4}\end{array}$ & $\begin{array}{l}95 \\
39\end{array}$ \\
\hline
\end{tabular}

Table 3. Specificity of APK: phosphorylation of guanidines

The reaction mixture contained guanidine $(2 \mathrm{mM})$, ATP (5 mM), $\mathrm{Mg}^{2+}$ ions (mM) and $N$-ethylmorpholine $(0.06 \mathrm{M}$, pH 8.4). The enzyme (final concn., $46 \mu \mathrm{g}$. of protein $/ \mathrm{ml}$.) was added and the tubes were incubated for $17 \mathrm{hr}$. at $5^{\circ}$. Total volume, $1.0 \mathrm{ml}$.

\begin{tabular}{lcc} 
Guanidine & \multicolumn{2}{c}{ Phosphorylation (\%) } \\
$\overbrace{(a)^{*}}$ & $(b) \dagger$ \\
L-Arginine & 88 & 91 \\
L-Arginine methyl ester & 65 & 67 \\
L-Canavanine & $\overline{23}$ & $\mathbf{1 9}$ \\
L-Homoarginine &
\end{tabular}

* (a) Calculated on basis of the free guanidine remaining. $\dagger$ (b) Calculated by determination of the guanidino $P$ formed.

Table 4. Spectrographic analysis of APK preparations

(a) Figures represent a visual assessment of the concentration of each metal on an ash basis.

$\begin{array}{lcccc} & >10 \% & 1-10 \% & 0 \cdot 1-1 \% & <0 \cdot 1 \% \\ \text { Sea crayfish } & \mathrm{Na}, \mathrm{Al}, \mathrm{Ca}, \mathrm{P} & \mathrm{Cu}, \mathrm{Si}, \mathrm{Mg}, \mathrm{Fe} & \mathrm{Mn} & \mathrm{B} \\ \text { Fresh-water crayfish } & \mathrm{Si}, \mathrm{Al}, \mathrm{Ca}, \mathrm{P} & \mathrm{Fe} & \mathrm{Cu}, \mathrm{Mg}, \mathrm{Pb} & \mathrm{Cd}, \mathrm{Mn}, \mathrm{Na}\end{array}$

(b) Comparison of the relative concentrations (in arbitrary units) of metals present in the ash of each preparation as determined from the spectrograms.

\begin{tabular}{|c|c|c|c|c|c|c|c|c|c|c|}
\hline Sample & $\begin{array}{l}\text { Ash } \\
(\%)\end{array}$ & $\mathrm{Na}$ & $\mathrm{Cu}$ & Al & $\mathrm{Si}$ & $\mathrm{Fe}$ & Mg & $\mathrm{Ca}$ & $\mathbf{P}$ & Mn \\
\hline $\begin{array}{l}\text { Sea crayfish } \\
\text { Fresh-water crayfish }\end{array}$ & $\begin{array}{l}2 \cdot 2 \\
0 \cdot 22\end{array}$ & $\begin{array}{l}10 \\
0 \cdot 05\end{array}$ & $\begin{array}{r}10 \\
7\end{array}$ & $\begin{array}{l}10 \\
10\end{array}$ & $\begin{array}{r}4 \\
10\end{array}$ & $\begin{array}{r}5 \\
10\end{array}$ & $\begin{array}{r}10 \\
6\end{array}$ & $\begin{array}{r}10 \\
7\end{array}$ & $\begin{array}{l}10 \\
10\end{array}$ & $\begin{array}{l}10 \\
0 \cdot 5\end{array}$ \\
\hline
\end{tabular}


The only experiments carried out with this APK preparation indicated that both $\mathrm{Mg}^{2+}$ and $\mathrm{Mn}^{2+}$ ions markedly activated the enzyme and that $\mathrm{Ca}^{2+}$ ions were without effect.

\section{Spectrographic analyses of APK preparations from fresh-water and sea crayfish}

APK preparations from fresh-water and sea crayfish were dialysed against nine changes of water at $5^{\circ}$ for three days and freeze-dried. The dry material was ashed and examined by arc spectrography.

The results (Table 4) of visual examination of the spectrograms indicated a much higher content of $\mathrm{Mg}^{2+}$ ions than of $\mathrm{Mn}^{2+}$ ions in both preparations. It is also of interest to note that both samples contained comparatively large amounts of $\mathrm{Ca}^{2+}$ ions, an ion which is incapable of activating the enzyme.

\section{DISCUSSION}

In the present work the major portion of the protein possessing APK activity was precipitated from the crude extract of sea-crayfish muscle in the fraction obtained between the addition of 31.5 and $42 \mathrm{~g}$. of ammonium sulphate $/ 100 \mathrm{ml}$; the enzyme remaining in the supernatant was of much lower specific activity. This result differs sharply from that of Soreni et al. (1949), who isolated crystals of APK from the supernatant obtained after the addition of $43 \cdot 2 \mathrm{~g}$. of ammonium sulphate $/ 100 \mathrm{ml}$. In one respect, however, the present results confirm those of these workers: diamond-shaped protein crystals were isolated from the supernatant $(43.2 \mathrm{~g}$. of ammonium sulphate $/ 100 \mathrm{ml}$.) after standing for $24 \mathrm{hr}$. in the cold room at $5^{\circ}$. These were identical in appearance with those (designated crystals $B$ ) photographed by Soreni et al. (1949), who did not identify them as possessing enzymic activity. Preliminary results have indicated that they possess glyceraldehyde-phosphate dehydrogenase activity, and on examination in the Perkin-Elmer electrophoresis apparatus at $\mathrm{pH} 8.6$ only one component was present.

An examination of fresh-water crayfish also failed to confirm the findings of Soreni et al. (1949), but it is of interest to note that whereas the fractionation pattern was different from that described by these workers it was also different from that observed in the sea-crayfish muscle. It is possible therefore that these differences may be due to species variation, but in any event it is apparent that the fractionation procedure described by Soreni et al. (1949) cannot be applied to the isolation of APK in crystalline form from the tail muscles of either sea-water or fresh-water crayfish available for the present work.
Differences in the properties of the APK described by Soreni et al. (1949) and those of our preparation are of a major nature. Thus the present results show that there is no loss of activity or of protein following dialysis against water and that the enzyme as isolated shows only slight activity in the absence of $\mathrm{Mg}^{2+}$ or $\mathrm{Mn}^{2+}$ ions. Soreni et al. (1949) have found that protein was precipitated when the enzyme was dialysed against water and that there was no separation of a cofactor after dialysis against a solution of ammonium sulphate. As no bivalent ions were added in the activity experiments it must be assumed that the enzyme was working at maximal activity, owing perhaps to the presence of $\mathrm{Mn}^{2+}$ ions bound to the enzyme. However, the analytical data, showing $\mathrm{Mn}^{2+}$ ion content of $0.27 \%$, refer only to mixed crystals of APK and an unknown protein. On the other hand spectrographic analysis of both the fresh-water and sea crayfish showed that $\mathrm{Mg}^{2+}$ ions were present in higher concentrations than $\mathrm{Mn}^{2+}$ ions. It is difficult to calculate the specific activity of the preparation described by Soreni et al. (1949) because the reaction rates were neither proportional to the enzyme concentrations nor linear with time. However, on the basis of an average value of the reaction rates at $30^{\circ}$ the specific activity may be calculated to be approximately 1.2 at $5^{\circ}$. This figure may be compared with a specific activity of $9 \cdot 2$ at $5^{\circ}$ obtained in the present work.

An ill-defined $\mathrm{pH}$ optimum for the reverse reaction in glycine buffer was found to lie at $\mathrm{pH} 8.4$ in the present work, whereas Soreni et al. (1949) have claimed a well-defined $\mathrm{pH}$ optimum, in the same buffer, at $\mathrm{pH} \mathrm{9 \cdot 1.} \mathrm{Another} \mathrm{difference} \mathrm{between} \mathrm{the}$ present results and those of the above authors lies in the isoelectric points; thus in crayfish APK the isoelectric point lies at about $\mathrm{pH} 5 \cdot 0$, but an unusually low figure of 3.5 was reported for crab APK.

$N$-Ethylmorpholine was chosen as the buffer for general work on the assumption that the concentration of free metal ion would not be reduced by reaction with the buffer and that thus complication of kinetic studies (to be reported) would be avoided. It is noteworthy therefore that the APK activity in the reverse reaction at the $\mathrm{pH}$ optimum is the same in $N$-ethylmorpholine as in glycine and glycylglycine, which coordinate with $\mathbf{M g}^{2+}$ ions (Monk, 1951). Moreover in the forward reaction the velocity of the enzymic reaction in $N$-ethylmorpholine is less than in phosphate and glycerophosphate buffers, which also form complexes with $\mathrm{Mg}^{2+}$ ions (Tabor \& Hastings, 1943). It seems therefore that under the conditions used there is no effective reduction of the $\mathrm{Mg}^{2+}$ ion concentration by the buffers which are capable of forming complexes with it.

The inhibition of enzymic activity by three classes of - $\mathrm{SH}$ reagents indicates that APK is 
dependent upon the presence of thiol groups for activity. The inhibition by iodoacetate characterizes the -SH group(s) of APK as 'freely reacting' according to the classification of thiol enzymes by Barron (1951). The inhibition by diphenylchloroarsine indicates that the enzyme forms a stable monothioarsenite, and the failure of arsenite to inhibit suggests that the thiol groups are not in sufficiently close proximity to form a stable As-ring (Peters, 1952). The inhibition of the reaction by DNP is of interest in occurring at the substrate rather than at the enzyme level. Doubtless a similar explanation would account for the inhibiting effect of 2:4-dinitro-o-cresol on creatine phosphokinase activity (Ennor \& Rosenberg, 1954).

The experiments on the specificity of APK give some indication of the groups required for interaction of the enzyme and substrate. The failure of the enzyme to phosphorylate argininic acid, agmatine, $\delta$-guanido- $n$-valeric acid and $\alpha$-carbamidoarginine suggests that the $\alpha$-amino group of arginine is an essential requirement of the substrate. The carboxyl group on the other hand is not essential, as evidenced by the fact that both arginine and arginine methyl ester were phosphorylated at the same rate. These results may be compared with those obtained with arginase (Greenberg, 1951), for which enzyme a free carboxyl group but not an $\alpha$-amino group is essential. An intact guanido group is required, as evidenced by the failure of APK to phosphorylate citrulline. The fact that homoarginine and canavanine are phosphorylated indicates that the enzyme is not absolutely specific. However, the rate of phosphorylation of these compounds is very slow. APK is similar to arginase and argininosuccinase (Greenberg, 1951; Walker, 1953) in that there is little or no differentiation between guanido and guanidoxy groups.

A comparison of the present results with those obtained with creatine phosphokinase by Kuby et al. (1954), Ennor \& Rosenberg (1954) and Rosenberg \& Ennor (1955) shows that there is a similarity in the properties of the two enzymes. Both are - SH enzymes of the monothiol type; both are activated by $\mathrm{Mg}^{2+}$ and $\mathrm{Mn}^{2+}$ ions, although creatine phosphokinase is also activated by $\mathrm{Ca}^{2+}$ ions. The $\mathrm{pH}$ optimum for the forward reaction in each case is about $\mathrm{pH} 7$ and for the reverse reaction is from pH 8.4 to 8.8. Under optimum conditions the velocity of each forward reaction is about six times as fast as the reverse reaction. This similarity is perhaps not surprising as the creatine phosphokinase-phosphocreatine system presumably plays the same role in the metabolism of vertebrate muscle as the arginine phosphokinase-phosphoarginine system plays in the metabolism of invertebrate muscle.

\section{SUMMARY}

1. A method is described for the isolation of a highly active preparation of arginine phosphokinase from the tail muscle of the sea crayfish (Jasus verreauxi). The purity was estimated to be $67-80 \%$.

2. The enzyme had a pH optimum of 6.6-7.0 and 8.4-8.5 in the forward and reverse reactions respectively, as expressed by the equation: Phosphoarginine + adenosine diphosphate $\rightleftharpoons$ arginine + adenosine triphosphate.

3. $\mathbf{M n}^{2+}$ and $\mathbf{M g}^{2+}$ ions activated the enzyme in both the forward and reverse reactions. There was no activation by $\mathrm{Ca}^{2+}$ ions.

4. The-SH nature of the enzyme was established as a result of the inhibition by iodoacetate, $p$ chloromercuribenzoate, etc. There was also inhibition by ethylenediaminetetraacetic acid and 2:4dinitrophenol.

5. The enzyme phosphorylated homoarginine and canavanine. There was no phosphorylation of agmatine, argininic acid, $\delta$-guanido- $n$-valeric acid, $\alpha$-carbamidoarginine, citrulline, creatine, negmine, glycocyamine, $\beta$-guanidopropionic acid or taurocyamine.

6. Adenosine 5'-phosphate could not act as a phosphate acceptor in the forward reaction. Inosine triphosphate or adenosine diphosphate could not replace adenosine triphosphate in the reverse reaction.

It is a pleasure to express our thanks to Mr F. Dempster of the Commonwealth Serum Laboratories, Melbourne, and to Mr R. Adams for carrying out the electrophoretic measurements. Our thanks are also due to MrD.J. David, Division of Plant Industry, C.S.I.R.O., Canberra, for the spectrographic analyses and to Mr D. Maguire for skilled technical assistance.

Note added in proof.

After this paper was submitted for publication the attention of the authors was drawn by the Editors to a paper (Szorenyi, Elodi \& Devenyi, 1956) in which the diamondshaped crystals isolated from a crab-muscle extract were shown to be D-glyceraldehyde 3-phosphate dehydrogenase:

\section{REFERENCES}

Baldwin, E. \& Needham, D. M. (1937). Proc. Roy. Soc. B, $122,197$.

Barron, E. S. G. (1951). Advanc. Enzymol. 11, 201.

Boon, W. R. \& Robson, W. (1935). Biochem. J. 29, 2573. Bousquet, E. W. (1943). Org. Synth. (Coll.), 2, 313.

Brand, E. \& Brand, F. C. (1942). Org. Synth. $22,59$.

Durrum, E. L. (1955). A Manual of Paper Chromatography d Paper Electrophoresis, p. 396. New York: Academic Press Inc.

Ennor, A. H., Morrison, J. F. \& Rosenberg, H. (1956). Biochem. J. 62, 358.

Ennor, A. H. \& Rosenberg, H. (1954). Biochem. J. 57, 203. Felix. K. \& Schneider, H. (1938). Hoppe-Seyl. Z. 255, 137. 
Fischer, E. \& Suzuki, V. (1905). Ber. dtsch. chem. Ges. 38, 4173.

Gornall, A. G., Bardawill, C. J. \& David, M. M. (1949). J. biol. Chem. 177, 151.

Greenberg, D. M. (1951). The Enzymes, vol. 1, p. 293. New York: Academic Press Inc.

Kerr, S. E. (1941). J. biol. Chem. 139, 131.

King, E. J. (1932). Biochem. J. 26, 292.

Kleinzeller, A. (1942). Biochem. J. 36, 729.

Kuby, S. A., Noda, L. \& Lardy, H. A. (1954). J. biol. Chem. 210, 65.

Lohmann, K. (1935). Biochem. Z. $282,109$.

Lohmann, K. (1936). Biochem. Z. 286, 28.

Monk, C. B. (1951). Trans. Faraday Soc. 47, 297.

Noda, L., Kuby, S. A. \& Lardy, H. A. (1954). J. biol. Chem. 210, 83.
Peters, R. A. (1952). Proc. Roy. Soc. B, 139, 143.

Rosenberg, H. \& Ennor, A. H. (1955). Biochim. biophys. Acta, 17, 261.

Rosenberg, H., Ennor, A. H. \& Morrison, J. F. (1956). Biochem. J. 63, 153.

Schniepp, L. E. \& Marvel, C. S. (1935). J. Amer. chem. Soc. 57, 1557.

Schutte, E. (1943). Hoppe-Seyl. Z. 279, 52.

Soreni, E. T., Dvornikova, P. D. \& Degtyar, R. G. (1949). C.R. Acad. Sci., U.R.S.S. 67, 341.

Stevens, C. M. \& Bush, J. A. (1950). J. biol. Chem. 183, 139.

Szorenyi, E., Elodi, P. \& Devenyi, T. (1956). Acta physiol. hung. 9, 351.

Tabor, H. \& Hastings, A. B. (1943). J. biol. Chem. 148, 627.

Walker, J. B. (1953). J. biol. Chem. 204, 139.

\title{
A Study of the Kinetics of the Reactions Catalysed by Arginine Phosphokinase
}

\author{
By D. E. GRIFFITHS*, J. F. MORRISON AND A. H. ENNOR \\ Department of Biochemistry, John Curtin School of Medical Research, The Australian National University, \\ Canberra, A.C.T., Australia
}

(Received 12 June 1956)

Some general properties of arginine phosphokinase (APK), which catalyses the approach to equilibrium of the reaction phosphoarginine+adenosine diphosphate $\rightleftharpoons$ arginine + adenosine triphosphate have been described in a previous communication (Morrison, Griffiths \& Ennor, 1957). Although the properties of the enzyme have also been studied to some extent by Lohmann $(1935 ; 1936)$ and Soreni, Dvornikova \& Degtyar (1949), no detailed study has been made of the kinetics of the reaction. This has been undertaken in the present work, which was also designed to elucidate the role of $\mathrm{Mg}^{2+}$ ions in the mechanism of the reaction. It has previously been reported that $\mathrm{Mg}^{2+}$ ions activate APK (Morrison et al. 1957), and it is well known that $\mathrm{Mg}^{2+}$ ions activate other phosphate-transferring enzymes (Lehninger, 1950). However, little work has been directed towards an understanding of the role of $\mathrm{Mg}^{2+}$ ions in phosphate-transfer reactions. The results reported in this communication indicate that $\mathrm{Mg}^{2+}$ ions react with APK to form an active Mg-APK complex which is responsible for catalysing the reaction as expressed above. In this paper the following abbreviations will be used: ATP, adenosine triphosphate; ADP, adenosine diphosphate; PA, phosphoarginine; APK, arginine phosphokinase.

* Australian National University Research Scholar.

\section{EXPERIMENTAL}

The materials and experimental methods, together with the preparation of the enzyme used in the present investigation, have been fully described in a previous publication (Morrison et al. 1957). The APK preparation had a purity of $67-80 \%$. The enzyme was stored at $5^{\circ}$ in the presence of an equal volume of glycerol and diluted with $0.05 \mathrm{M} N$-ethylmorpholine of the appropriate $\mathrm{pH}$ before addition to the test system. Although the preparation was contaminated by myokinase, the activity of this enzyme was not detectable at the low enzyme concentrations and short reaction periods used for the kinetic studies. Even with the larger enzyme concentrations and longer incubation periods used for the equilibrium experiments, it appeared that the presence of myokinase did not influence the equilibrium values. The detailed descriptions of the experimental conditions are given in the legends to the figures and tables. All experiments have been carried out at $5^{\circ}$ for reasons previously explained (Morrison et al. 1957). The $K_{m}$ values represent a measure of the substrate concentration required for halfmaximum velocity and are not necessarily true dissociation constants of the enzyme-substrate complexes.

The reactions, $\mathrm{PA}+\mathrm{ADP} \rightarrow$ arginine $+\mathrm{ATP}$ and arginine $+\mathrm{ATP} \rightarrow \mathrm{PA}+\mathrm{ADP}$ are taken as the forward and reverse reactions respectively.

\section{RESULTS}

Effect of bivalent cations on the reaction velocity. The effect of $\mathrm{Mg}^{2+}$ ion concentration on the reaction velocity of the reverse and forward reactions is 